\title{
Screening of Bacteria for Lactic Acid Production from Whey Water
}

\author{
${ }^{1}$ Vethakanraj Helen Shiphrah, ${ }^{1}$ Sayanti Sahu, \\ ${ }^{2}$ Ashoke Ranjan Thakur and ${ }^{\mathbf{1}}$ Shaon Ray Chaudhuri \\ ${ }^{1}$ Department of Biotechnology, \\ School of Biotechnology and Biological Sciences, West Bengal University of Technology, \\ BF-142, Sector-1, Salt Lake, Kolkata-700064, West Bengal, India \\ ${ }^{2}$ Vice Chancellor's Unit, Techno India University, EM-4/1, Sector-V, Salt Lake, Kolkata-700009, India
}

Received 2012-11-26, Revised 2013-04-19; Accepted 2013-05-03

\begin{abstract}
Lactobacilli have the property of converting lactose and other sugars to lactic acid through fermentation. So whey water, the greenish translucent liquid rich in lactose, vitamins, proteins and mineral salts, obtained as a by-product after the precipitation of cheese can be used as a substrate for Lactobacilli for lactic acid production which otherwise is a serious environmental pollutant when disposed without pre-treatment. 16 isolates of Lactic acid producing bacteria isolated from various biological sources were inoculated in whey water $\left(1 \%\right.$ inoculum) and kept at $37^{\circ} \mathrm{C}$ in the shaker at a speed of 150 revolutions per minute for $36 \mathrm{~h}$. Lactic acid production was estimated after $36 \mathrm{~h}$ and the strains $4 \mathrm{a}, 12 \mathrm{a}$ and $15 \mathrm{~b}$ showed lactic acid production of which 12 a produced the highest concentration. The amount of Lactic acid produced by 12a was $0.62 \mathrm{~g} \mathrm{~L}^{-1}$ under unadjusted condition which is comparable to previously reported strains in enriched medium. So the lactic acid production by strain $12 \mathrm{a}$ was further investigated to find the effect of $\mathrm{pH}$ and temperature on the production efficiency. Lactic acid production was also checked in Luria-Bertani broth and whey water was found to be the medium of choice for prolonged lactic acid production.
\end{abstract}

Keywords: Lactobacilli, Lactic Acid, Whey Water, Biological Oxygen Demand

\section{INTRODUCTION}

Lactobacilli are gram positive (Abedon, 1998), non spore forming cocci, coccobacilli or rods. Since these organisms have the property of producing lactic acid from lactose and other carbon sources through fermentation they are classified as Lactic Acid Bacteria (LAB). All the members of this group can grow anaerobically and they can also tolerate oxygen due to the presence of superoxide dismutase which detoxifies the free radicals and hence the name aero tolerant anaerobes. LABS obtain energy from the metabolism of sugars. So they are present only in environments containing sugar like in the oral cavity, the intestinal tract and the vagina (Dicks et al., 2000). They produce antimicrobial peptides called Bacteriocins which help this group of organisms to kill the harmful microorganisms around the environment. Lactic acid bacteria have anti-inflammatory and anti-cancer activity (Chen et al., 2009). Few of the Lactobacilli are pathogenic to animals. In humans Streptococcus pneumoniae causes lobar pneumonia, otitis media and meningitis (Aguirre and Collins, 1993); some viridans and nonhemolytic oral streptococci play a role in dental caries (Tasli et al., 2006).

LAB produce organic (acetic and lactic) acid which inhibits the growth of many bacteria especially pathogenic gram negative bacteria. The antimicrobial activity occurs through the diffusion of lactic molecules into microbial cells until equilibrium is reached, in accordance with the $\mathrm{pH}$ gradient, causing membrane disruption, inhibition of essential metabolic reactions, West Bengal University of Technology, BF-142, Sector-1, Salt Lake, Kolkata-700064, West Bengal, India 
stress on intracellular $\mathrm{pH}$ homeostasis and accumulation of toxic anions and ultimately death of microbial cells (Brul and Coote, 1999). Besides the anti-microbial activity Lactic acid also has wider applications in food, cosmetic, pharmaceutical and chemical industries because of the increasing market demand for the naturally produced lactic acid (i.e., 130,000-150,000 tonnes/year) (Mirasol, 1999). The fact that $10 \%$ of lactic acid produced is by synthetic means from Lactonitrile, it would be better to recycle the industrial wastes like whey water which are rich in lactose for Lactic acid production which otherwise pollutes the environment.

Whey water, the greenish translucent liquid obtained after the precipitation of cheese is a very good source of lactose, proteins, vitamins and minerals which in turn is responsible for the foul smell generated during decomposition of it upon discharge (Mukhopadhyay et al., 2003). Every year $10^{8}$ tonnes of whey water is produced and for $1 \mathrm{Kg}$ of cheese produced 9 litres of whey water is obtained as effluent (Zafar and Owais, 2006). When this whey water is disposed to the environment without pretreatment, it pollutes the water bodies by increasing the biological oxygen demand in the range of 38,000 to $46,000 \mathrm{ppm}$ as opposed to $200 \mathrm{ppm}$ in case of sewage (Marwaha and Kennedy, 1988; Mawson, 1994). About 1, 50,000 tonnes of cottage cheese and 2 million tonnes of whey (with about 1,30,000 tones of milk nutrients) are produced annually in India (Dernirel et al., 2005). These were some of the facts that led to the formation of the Environmental protection Act-1986 by the Government of India making it obligatory to pre treat the dairy effluent (whey) before discharging into the environment.

This study concentrates on the isolation of Lactic acid Bacteria from various biological sources and screening the 16 strains for lactic acid production in both Whey water and Luria-Bertani (LB) broth and immobilising the strains with higher lactic acid production for the continuous generation of lactic acid.

\section{MATERIALS AND METHODS}

\subsection{Screening of Lactic Acid Bacteria}

For screening, total numbers of LAB colonies were counted after overnight incubation of samples in LB agar plates containing $0.4 \% \mathrm{CaCO}_{3}$ at $37^{\circ} \mathrm{C}$. List of samples collected were as follows: (1) Milk, (2) Cheese, (3) Fruit Juice, (4) Sambar, (5) Chutni, (6) Sweet yoghurt, (7) Sour yoghurt, (8) Country Liquor, (9) Idli Batter, (10) Labeo rohita (intestine), (11) Raiamas bola. (intestine), (12) Catla catla (intestine), (13) Penaeus indicus (Flesh), (14) Probiotic (prowel), (15) Probiotic (Laviest), (16) Probiotic (Binifit), (17) Packet Milk (pasteurized), (18)
Pastry, (19) Buttermilk, (20) Mango pickle, (21) Chilli pickle, (22) Pickle filler, (23) Solanum tuberosum, (24) Solanum lycopersicum, (25) Malus domestica. (Juice), (26) Musa acuminata (rotten), (27) Grapes (rotten), (28) Mangifera indica (rotten), (29) Solanum melongena (rotten), (30) Allium cepa, (31) Oreochromis niloticus niloticus (intestine), (32) Heteropneutes fossilis. (intestine), (33) Sus scrofa domesticus (flesh), (34) Sus scrofa domesticus (intestine), (35) Puntius sp. (intestine), (36) Gallus domesticus(flesh), (37) Gallusdomesticus (intestine), (38) Capra hircus (meat), (39) Capra hircus (intestine), (40) Long grass, (41) Grass (shoot), (42) Bitter gourd grass, (43) Curry leaves, (44) Tomato leaves.

Small portion of each samples were mixed with sterile Phosphate Buffer Saline (PBS). The leaf samples were sonicated in $5 \mathrm{~mL}$ PBS for $14 \mathrm{~min}$ at maximum frequency (not to lyse the cells). The samples were serially diluted to $1 \times 10^{-8}$ dilution and $50 \mu \mathrm{L}$ of each of the samples were spread in LB agar plates containing $0.4 \% \mathrm{CaCO}_{3}$. The Petri plates were kept in inverted position for overnight incubation at $37^{\circ} \mathrm{C}$. The Lactic acid bacteria were demarcated by having a clearing zone.

\subsection{Starter Culture}

16 Lactobacilli strains from glycerol stock were inoculated in $2 \mathrm{~mL}$ Luria-Bertani medium and allowed to grow for $24 \mathrm{~h}$ at $37^{\circ} \mathrm{C}$ in a shaker which runs at a speed of 150 revolutions per minute.

\subsection{Preparation of Whey Medium}

Whey medium was prepared by boiling the milk and then precipitating the casein in the milk by adding citric acid (for $250 \mathrm{~mL}$ of milk, lime juice obtained from one lemon was used). The whey water obtained by this method was purified by centrifuging it at $16000 \mathrm{~g}$ for $10 \mathrm{~min}$ followed by filtering through a $0.45 \mu$ filter. $2 \mathrm{~mL}$ of the pure whey water was transferred into sterile tubes inside laminar flow hood. The $\mathrm{pH}$ of the whey media was between 4.5-5.0 and no nutrient supplements were added. The media was now ready for inoculation of isolated strains.

\subsection{Preparation of LB Medium}

LB medium was prepared by adding 1\% Tryptone, $0.5 \%$ yeast extract and $0.5 \%$ sodium chloride in water with $\mathrm{pH}$ of 7.5 and autoclaved at $121^{\circ} \mathrm{C}$ for $15 \mathrm{~min}$.

\subsection{Inoculation of Culture}

Each tube containing whey medium and LB medium was inoculated with the 16 strains ( $1 \%$ inoculum) separately and allowed to grow for $36 \mathrm{~h}$ in the case of whey water and $24 \mathrm{~h}$ in the case of $\mathrm{LB}$ at $37^{\circ} \mathrm{C}$ in a shaker 
which runs at a speed of 150 revolutions per minute. After respective period of incubation, the cultures were taken out and the Lactic acid test was performed.

\subsection{Lactic Acid Test}

Lactic acid was measured by modified Barker and Summerson (1941) method. Lactic acid was first oxidised with strong Sulphuric acid solution to acetaldehyde and then it was coupled with p-hydroxy diphenyl in the presence of cupric ions to yield a purple compound. The absorbance of purple compound was measured using spectrophotometer at $560 \mathrm{~nm}$. In biological material the protein content must be first precipitated prior to measuring the Lactic acid concentration.

\subsection{Preparation of Protein Free Supernatant}

The sample was made protein free by treating the supernatant which was obtained after centrifugation $(16000 \mathrm{~g}$ for $10 \mathrm{~min})$ with $100 \mu \mathrm{L}$ of $100 \%$ Trichloroacetic acid for each $1 \mathrm{~mL}$ of sample. This was followed by incubation in ice for $30 \mathrm{~min}$ and centrifugation at $16000 \mathrm{~g}$ for $5 \mathrm{~min}$ for collection of protein free supernatant.

\subsection{Treatment with Copper and Calcium}

Treatment with copper sulphate and calcium hydroxide is done to remove any interfering material. 1 $\mathrm{mL}$ of the protein free supernatant obtained by the above method was diluted to $9 \mathrm{~mL}$ with distilled water and $1 \mathrm{~mL}$ of $20 \%$ copper sulphate was added to this followed by addition of $1 \mathrm{gm}$ of calcium hydroxide. The mixture was shaken vigorously. The above mixture was allowed to stand at room temperature for atleast half an hour with occasional shaking followed by centrifugation at $16000 \mathrm{~g}$ for $10 \mathrm{~min}$.

\subsection{Colour Development}

To $1 \mathrm{~mL}$ of supernatant obtained after centrifugation, $0.05 \mathrm{~mL}$ of $4 \%$ copper sulphate solution and $6 \mathrm{~mL}$ of concentrated sulphuric acid were added with continuous mixing. The mixture was boiled in $100^{\circ} \mathrm{C}$ water bath for 5 min followed by placing in cold water. After cooling $0.1 \mathrm{~mL}$ of alkaline solution of p-hydroxy diphenyl was added and the tubes were placed in $30^{\circ} \mathrm{C}$ water bath for $30 \mathrm{~min}$. The tubes were again placed in $100^{\circ} \mathrm{C}$ water bath for $90 \mathrm{sec}$ to dissolve the excess reagents. The above solution was then cooled and the absorbance was taken at $560 \mathrm{~nm}$. The concentration of lactic acid produced was estimated by using known concentration of sodium lactate as standard.

\subsection{Optimisation of $\mathrm{pH}$ and Temperature for the Screened Strain}

\subsubsection{Effect of $\mathbf{p H}$}

For optimising the $\mathrm{pH}$ the fermentation medium (whey water) was adjusted to five different $\mathrm{pH}(5.0,5.5$, $6.0,6.5,6.8)$ and kept in $37^{\circ} \mathrm{C}$ shaker which runs at a speed of 150 revolutions per minute and the Lactic acid production was checked for each $\mathrm{pH}$ after $12 \mathrm{~h}$. The optimised $\mathrm{pH}$ was maintained for further work.

\subsection{Effect of Temperature}

Whey water with adjusted $\mathrm{pH}$ was maintained at five different temperatures $\left(30,35,37,40\right.$ and $\left.45^{\circ} \mathrm{C}\right)$ by keeping them in the respective shakers running at a speed of $150 \mathrm{rpm}$ and the lactic acid production was estimated after $12 \mathrm{~h}$.

\subsection{Continuous Generation of Lactic Acid in Whey Water and LB Broth}

2.5 litres of whey water and LB medium containing $5 \%$ inoculum of isolate $12 \mathrm{a}$ were taken in respective bioreactors packed with corrugated sheets. The cultures were allowed to grow for $18 \mathrm{~h}$ inside the bioreactor before being drained and kept dry for immobilization for $6 \mathrm{~h}$. After $6 \mathrm{~h}$, fresh whey water and LB were added to the respective. Lactic acid production was checked every $24 \mathrm{~h}$ and the whole process were repeated till there was a decline in lactic acid production.

\subsection{Strain Characterization}

The isolate capable of producing lactic acid from whey water was characterized at length as per earlier reports (Nandy et al., 2007). It was further characterized at the molecular level (16S rDNA) as per the method reported earlier (Chaudhuri and Thakur, 2006). The partial sequences obtained were subjected to Blast analysis and the novel sequences were submitted to GenBank.

\section{RESULTS}

Out of the forty four different samples that were tested for probable sources of lactic acid bacteria, not all were identified as potential sources of these bacteria. A comparison of the percentage of LAB obtained from the different sources can help us designate the sources according to the percentage of LAB obtained and hence the sources were classified as the most potential sources of $\mathrm{LAB}$ (from which $>80 \%$ of $\mathrm{LAB}$ was isolated); potential sources of LAB (from which $>60 \%$ of LAB was isolated); probable sources of LAB (from which $>40 \%$ of LAB were isolated); least probable sources of $\mathrm{LAB}$ (from which $<40 \%$ of $\mathrm{LAB}$ were isolated). 


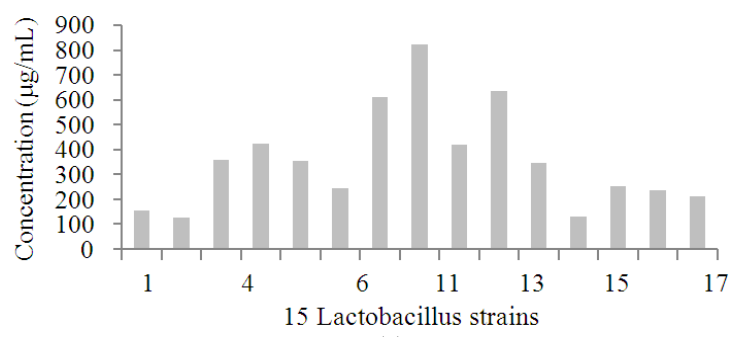

(a)

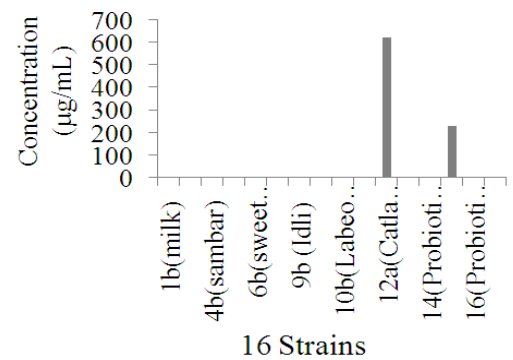

(b)

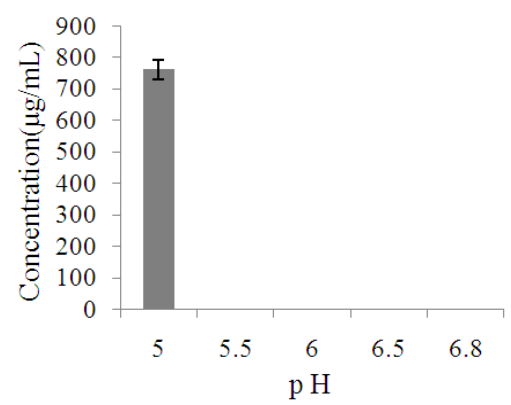

(c)

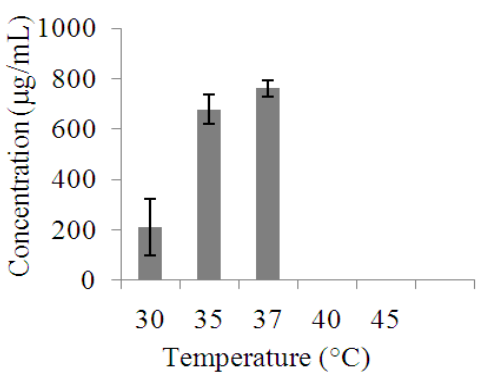

(d)

Fig. 1. Lactic acid production by bacterial isolates. (a) Lactic acid production in LB after $24 \mathrm{~h}$ of growth by the $15 \mathrm{LAB}$ isolates namely $1 \mathrm{~b}, 3 \mathrm{~b}, 4 \mathrm{~b}, 5 \mathrm{~b}, 6 \mathrm{~b}, 7 \mathrm{~b}, 9 \mathrm{~b}, 10 \mathrm{a}, 11 \mathrm{~b}, 12 \mathrm{a}$, $13 \mathrm{~b}, 14,15 \mathrm{~b}, 16,17$ as per the source of isolation mentioned in the materials and method; (b) Screening of Lactic acid production by 16 selected strains $(1 \mathrm{~b}, 3 \mathrm{~b}, 4 \mathrm{~b}$, $5 \mathrm{~b}, 6 \mathrm{~b}, 7 \mathrm{~b}, 9 \mathrm{~b}, 10 \mathrm{a}, 10 \mathrm{~b}, 11 \mathrm{~b}, 12 \mathrm{a}, 13 \mathrm{~b}, 14,15 \mathrm{~b}, 16,17)$ in whey water after $36 \mathrm{~h}$ of growth; (c) Effect of $\mathrm{pH}$ on lactic acid production by isolate $12 \mathrm{a}$ in whey water after $12 \mathrm{~h}$ of growth; (d) Effect of Temperature on lactic acid production by isolate 12a in whey water after $12 \mathrm{~h}$ of growth

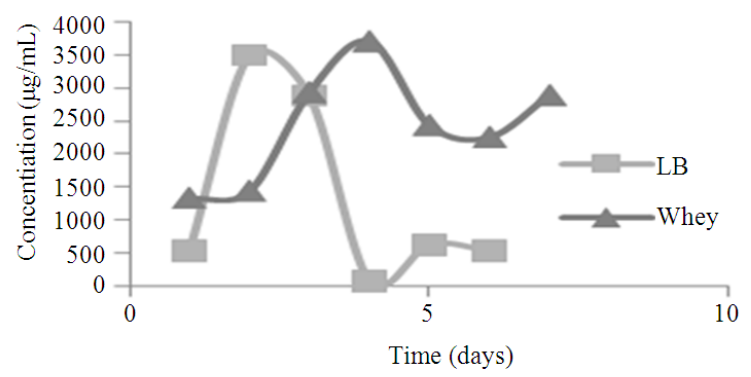

Fig. 2. Comparison of lactic acid production by isolate 12a in Luria Bertani and whey water

In LB all the Lactobacillus strains had produced lactic acid of which isolate $10 \mathrm{~b}$ had produced $0.823 \mathrm{~g} \mathrm{~L}^{-1}$ and isolate $12 \mathrm{a}$ had produced $0.634 \mathrm{~g} \mathrm{~L}^{-1}$ (Fig. 1a). Among the 16 strains checked 3 strains isolated from sambar (4b), Catla catla-intestine (12a), ProbioticLaviest (15b) have produced Lactic acid after $36 \mathrm{~h}$ of which the production was too low in the sambar strain (4b). The concentration of Lactic acid produced by Catla-catla strain (12a) and Probiotic-Laviest strain (15b) were $6.9 \mathrm{mM}\left(0.62 \mathrm{~g} \mathrm{~L}^{-1}\right)$ and $2.5 \mathrm{mM}(0.23 \mathrm{~g}$ $\left.\mathrm{L}^{-1}\right)$. Since $12 \mathrm{a}$ had produced higher amount compared to 15b (Fig. 1b), it had been screened for optimisation and continuous generation of lactic acid.

Since isolate $12 \mathrm{a}$ had produced lactic acid in both LB and Whey water, it was screened for optimization of lactic acid production in whey water and also for the continuous generation of lactic acid both in LB and Whey water in a packed bed bioreactor.

Isolate 12a produced more amount of lactic acid when the whey water $\mathrm{pH}$ was adjusted to 5.0 (Fig. 1c) and it was optimised for further work. The concentration of lactic acid produced was $0.761 \mathrm{~g} \mathrm{~L}^{-1}$. Whey water culture maintained at $37^{\circ} \mathrm{C}$ (Fig. 1d) had produced higher amount of lactic acid compared to the other temperatures and the amount of lactic acid produced was $0.761 \mu \mathrm{g} \mathrm{mL}^{-1}$.

\subsection{Immobilisation for Continuous Generation of Lactic Acid}

On first day whey water $\left(1.333 \mathrm{~g} \mathrm{~L}^{-1}\right)$ produced higher concentration of lactic acid compared to Luria Bertani broth $\left(0.540 \mathrm{~g} \mathrm{~L}^{-1}\right)$ but on the second day production was higher in LB $\left(3.495 \mathrm{~g} \mathrm{~L}^{-1}\right)$ compared to whey water $\left(1.494 \mathrm{~g} \mathrm{~L}^{-1}\right)$. LB medium produced higher concentration of lactic acid within a short duration but for prolonged production of lactic acid, whey water would be a better carbon source for LAB isolate 12a (Fig. 2). 


\subsection{Strain Characterization}

This strain (12a) was oxidase positive as well as gram positive cocci (at 100X magnification of Axiostar Plus, Zeiss). But at the molecular level it was closest to Bacillus sp (Bacillus sp. strain SRCkk.01) with the following taxonomic identity: Firmicutes; Bacilli; Bacillales; Bacillaceae; Bacillus. The GenBank accession number of its partial 16S rDNA sequence is GQ979935. It lacks capsule, endospore, DNase, lipase, protease, catalase and lecithinase formation. Of the antibiotics tested [Ampicillin (A, $10 \mu \mathrm{g})$, Cephadroxil $(\mathrm{Cq}, 30 \mu \mathrm{g})$, Chloramphenicol $(\mathrm{C}, 30 \mu \mathrm{g})$, Cloxacillin $(\mathrm{Cx}, 10 \mu \mathrm{g})$, Cephotaxime (Ce, $30 \mu \mathrm{g})$, Ceftazidime (Ca, $30 \mu \mathrm{g})$, Ciprofloxacin (Cf, $5 \mu \mathrm{g})$, Doxycycline Hydrochloride (Do, $30 \mu \mathrm{g})$, Gentamicin (G, $10 \mu \mathrm{g}$ ), Metronidazole (Mt, $4 \mu \mathrm{g})$, Neomycin (N, $30 \mu \mathrm{g})$, Norfloxacin (Nx, $10 \mu \mathrm{g})$, Polymyxin B (Pb, 100 units), Rifampicin (R, $15 \mu \mathrm{g})$, Roxithromycin (Ro, $30 \mu \mathrm{g}$ ), Tetracycline ( $\mathrm{T}, 30 \mu \mathrm{g})$, Trimethoprin ( $\mathrm{Tr}, 30 \mu \mathrm{g})$, Vancomycin (Va, $30 \mu \mathrm{g}$ )], the strain was sensitive to Chloramphenicol, Ampicillin, Roxithromycin and Cloxacillin. The minimum inhibitory concentration for metals like copper, lead, nickel and chromium in solution was $6 \mathrm{mM}, 7 \mathrm{mM}, 2 \mathrm{mM}$ and $1 \mathrm{mM}$ respectively. It could grow in a temperature range of 20 to $37^{\circ} \mathrm{C}$ with optimum growth at $20^{\circ} \mathrm{C}$. The optimum $\mathrm{pH}$ for growth of the cell was 6 to 7.5. It could grow equally well in presence and absence of light. It could utilize the following carbohydrate sources: maltose, fructose, dextrose, galactose, sucrose, mannose, ribose, esculin, D-arabinose, citrate and malonate.

\section{DISCUSSION}

We observed that the various milk products and milk itself has the maximum content of lactic acid bacteria. Though pastry and buttermilk are also milk products but LAB could not be found may be because these are processed food products. Out of the different animals and fishes tested only intestine and flesh of Gallus domesticus, intestine of Capra hircus and intestine of Puntius sp. can be categorized as the sources from which $100 \%$ of LAB was isolated. Pickles are considered as good sources of LAB but in our experiment we could not isolate any $\mathrm{LAB}$ from them. This may be because of the high salt content used for the preservation of pickles which in turn makes the survival of LAB unfavourable. Fruits were also shown to be poor sources of LAB. Out of the grasses and vegetables that we chose, only the long grass variety was observed to be a potential source of LAB.
Catla catla strain (12a) had produced $0.62 \mathrm{~g} \mathrm{~L}^{-1}$ of lactic acid after $36 \mathrm{~h}$ even at a $\mathrm{pH}$ of 4.63 and without any nutrient supplements. After adjusting the $\mathrm{pH}$ and temperature, the strain produced $0.761 \mathrm{~g} \mathrm{~L}^{-1}$ of lactic acid after $12 \mathrm{~h}$. But Lactobacillus caesi had produced $33.73 \mathrm{~g} \mathrm{~L}^{-1}$ of lactic acid after an incubation period of 36 $\mathrm{h}$ with added nutrient supplements like yeast extract, Magnesium sulphate, calcium carbonate under optimised process parameters.

Lactic acid production was observed only in $\mathrm{pH} 5.0$ and this is due to the ability of this particular strain $12 \mathrm{a}$ to survive under acidic conditions. A pH range of 6.0-6.5 has been optimised for $L$. caesi. However, in the case of L. helveticus the optimised $\mathrm{pH}$ was 5.5. Lactic acid production was observed at $30^{\circ} \mathrm{C}, 35^{\circ} \mathrm{C}, 37^{\circ} \mathrm{C}$ but the production was high at $37^{\circ} \mathrm{C}$ and this is the optimised temperature for this isolate $12 \mathrm{a}$. The optimal temperature for Lactobacillus varies between $20-45^{\circ} \mathrm{C}$.

In $2.5 \mathrm{~L}$ bioreactor both whey water and LB has started producing lactic acid after $24 \mathrm{~h}$. In whey water the production was higher on the fourth day (3.69 g $\mathrm{L}^{-1}$ ) and then its shows a zig-zag pattern and this could be due to the shedding of Bio-film. In LB the highest production was observed on the second day (3.495 $\mathrm{g} \mathrm{L}^{-1}$ ) and then it started declining and this could be due to accumulation of toxins and by products. Thus whey water can be utilised for the continuous generation of lactic acid.

\section{CONCLUSION}

The potential of using this isolate for bioremediation of dairy waste (whey water) could be explored and exploited in future. This would ensure conversion of waste product into a by product with immense commercial application.

\section{ACKNOWLEDGEMENT}

The researchers are thankful to Department of Biotechnology, Govt of India for providing financial assistance; West Bengal University of Technology for the laboratory as well as computational facility; $\mathrm{Mr}$ Sourav Ghosh for editing and formatting the manuscript.

\section{REFERENCES}

Abedon, T.S., 1998. Supplemental lecture.

Aguirre, M. and M.D. Collins, 1993. Lactic acid bacteria and human clinical infection. J. Applied Bacteriol., 75: $\quad 95-107 . \quad$ DOI: $\quad 10.1111 /$ j.13652672.1993.tb02753.x 
Barker, S.B. and W.H. Summerson, 1941. The colorimetric determination of lactic acid in biological material. J. Biol. Chem., 138: 535-554.

Brul, S. and P. Coote, 1999. Preservative agents in foods: mode of action and microbial resistance mechanisms. Int. J. Food Microbiol., 50: 1-17. DOI: 10.1016/S0168-1605(99)00072-0

Chen, X., J. Fruehauf, J.D. Goldsmith, H. Xu and K.K. Katchar et al., 2009. Saccharomyces boulardii inhibits EGF receptor signaling and intestinal tumor growth in apc ${ }^{\min }$ mice. Gastroenterology, 137: 914923. DOI: 10.1053/j.gastro.2009.05.050

Dernirel, B., O. Yeniguri and T.T. Onay, 2005. Anaerobic treatment of dairy wastewaters: A review. Process Biochem., 40: 2583-2595. DOI: 10.1016/j.procbio.2004.12.015

Dicks, L.M.T., M. Silvester, P.A. Lawson and M.D. Collins, 2000. Lactobacillus fornicalis sp. nov., isolated from the posterior fornix of the human vagina. Int. J. Food Microbial., 50: 1253-1258. PMID: 10843070

Marwaha, S.S. and J.F. Kennedy, 1988. Whey-pollution problem and potential utilization. Int. J. Food Sci. Technol., 23: 323-336. DOI: 10.1111/j.13652621.1988.tb00586.x
Mawson, A.J., 1994. Bioconversions for whey utilization and waste abatement. Biores. Technol., 47: 195-203. DOI: 10.1016/0960-8524(94)90180-5

Mirasol, F., 1999. Lactic acid prices falter as competition toughen. Chem. Market Reporter.

Mukhopadhyay, R., D. Talukdar, B.P. Chatterjee and A.K. Guha, 2003. Whey processing with chitosan and isolation of lactose. Process Biochem., 39: 381385. DOI: 10.1016/S0032-9592(03)00126-2

Nandy, P., A.R. Thakur and S.R. Chaudhuri, 2007. Characterization of bacterial strains isolated through microbial profiling of urine samples. Online J. Biol. Sci., 7: 44-51. DOI: 10.3844/ojbs.2007.44.51

Chaudhuri, S.R. and A.R. Thakur, 2006. Microbial genetic resource mapping of East Calcutta wetland. Curr. Sci., 91: 212-217.

Tasli, L., C. Mat, C. De Simone and H. Yazic, 2006. Lactobacilli lozenges in the management of oral ulcers of Behcet's syndrome. Clin. Exp. Rheumatol., 24: S83-S86. PMID: 17067433

Zafar, S. and M. Owais, 2006. Ethanol production from crude whey by Kluyveromyces marxianus. Biochem. Eng. J., 27: 295-298. DOI: 10.1016/j.bej.2005.05.009 